tionized. In the American Army camps, the death. rate has been only $3 \frac{1}{2}$ per cent as compared with 34 per cent in the War of 1914-18; relapses have been virtually eliminated and the frequency of complications has been greatly reduced.

\section{Training in Special Librarianship}

THE very great increase in information services has created a demand for special librarians and informa. tion officers far in advance of the available supply of trained librarians. The Association of Special Libraries and Information Bureaux is therefore continuing to organize its emergency training in the technique of the special library by means of courses of twelve lectures given at weekly intervals, the first of which will start on February 16. Naturally such courses cannot pretend to give a complete training in librarianship; they are intended as first-aid help for inexperienced assistants in special libraries or information bureaux in place of the more thorough training not obtainable through war conditions. In the light of the experience gained in 1943, modifications have been made in the syllabus, which can be obtained on application to the General Secretary, ASLIB, 31 Museum Street, London, W.C.1. A fee of five guineas per student is charged for the course.

\section{Clough Memorial Research Fund}

THIs fund was instituted in 1935 for the purpose of encouraging geological research in Scotland and the north of England, the latter defined as comprising the counties of Northumberland, Cumberland, Durham, Westmorland and Yorkshire. A sum of approximately $£ 30$ is available annually. Applications for grants for the period April 1, 1944, to March 1945 are invited. Applications should state the nature of research to be undertaken, the amount of grant desired and the specific purpose for which it will be used, and whether any other grant-in-aid has been obtained or applied for. Applications must be in the hands of the Secretary, Clough Research Fund Committee, Edinburgh Geological Society, Synod Hall, Edinburgh, not later than March 1, 1944.

\section{Recent Earthquakes}

DuRrva September 1943, ten strong earthquakes were registered at the Dominion Observatory, Wellington, New Zealand. Epicentres have been determined at the Observatory as follow : September 6, near Macquarie Island; September 14, (1) near New Caledonia; (2) Samoa region; (3) region of $26^{\circ}$ S., $175^{\circ}$ W.; September 17 , near Solomon Islands ; and September 27, in the Kermedecs region. Sixteen other earthquakes and tremors were felt in New Zealand during the month. The strongest of these was Scale IV on the Modified Mercalli scale, and shocks with this intensity occurred on (1) September 3 , in parts of Canterbury and Westland ; (2) Septernber 12 in Otira and near Arthur's Pass ; and (3) Sep. tember 28 at Eketahuna. Seismographs at Toledo in Spain registered twenty-two strong earthquakes during September 1943, the shocks of September 6, 10 and 14 being described as violent.

During the period Sept. 11-Nov. 26 inclusive, twenty strong earthquakes were registered at Kew Observatory. By far the largest ground vibration amplitudes at Kew were on Nov. 26, $1120 \mu$; Nov. 6, $590 \mu$; Oct. 23, 340 $\mu$; and Nov. 3, $330 \mu$. The shock of Nov. 26 was in Turkey and has already been reported in NATuRE (Dec. 11, p. 684). The shock of Nov. 6 was probably the one with epicentre just west of the island of Aroe Eilanden in the Banda Sea (lat. $5 \cdot 5^{\circ}$ S., long. $134^{\circ}$ E.). The earthquake of October 23 probably had its epicentre 30 miles eastnorth-east of Sylhet in Assam, while that of November 3 probably originated 30 miles north-west of Susitna in Alaska. The last three mentioned epicentres were determined provisionally by the United States Coast and Geodetic Survey in co-operation with Science Service and the Jesuit Seismological Association on instrumental evidence. The next largest amplitudes during the period at Kew were Nov. 24, $105 \mu$; Oct. 24, $32 \mu$; Sept. 24, $28 \mu$; Oct. $22,25 \mu$; Oct. $16,21 \mu$; and Oct. $21,17 \mu$. The last-named had its epicentre determined by the U.S. Coast and Geodetic Survey as being near lat. $16.5^{\circ}$ S., long. $178^{\circ}$ E., which is in the Pacific Ocean due north of the island of Vita Levu and due west of the island of Vanua Levu, both of the Fiji Islands group.

\section{Announcements}

The Council of the Institute of Metals has elected four honorary members of the Institute, one each from the four principal Allied Nations : Her Excellency Madame Chiang Kai-Shek (China); Sir Lawrence Bragg (Great Britain); Dr. Irving Langmuir (United States of America); Prof. P. Kapitza (Union of Soviet Socialist Republics).

The Astronomer Royal, Sir Harold Spencer Jones, will deliver the 1944 May Lecture of the Institute of Metals. He has chosen as his subject "Metals in the Stars".

THE Council of Newnham College, Cambridge, has awarded a Muriel Wheldale Onslow Prize for outstanding work in biology to Dr. A. B. Beakbane, of the East Malling Research Station.

Prof. J. McLean Thompson will read a paper entitled "Towards a Physiological Interpretation of Modern Flowering", before the Linnean Society on February 10 , at 2.30 p.m.

Dr. Paux Herget, formerly assistant professor of astronomy at the University of Cincinnati, has been appointed director of Cincinnati Observatory in succession to the late Dr. Elliott Smith, and has been made professor and head of the Department of Astronomy in the University of Cincinnati. Dr. Herget, who is thirty-five years old, is an authority on celestial mechanics, having specialized on the computation of the orbits of minor planets and comets.

AT the annual meeting of the New York Academy of Sciences held on December 15, the following were elected to honorary life membership: Dr. O. T. Avery, of the Rockefeller Institute for Medical Research, New York ; Prof. Alexander Fleming, professor of bacteriology, University of London (St. Mary's Hospital Medical School); Sir Frederick Gowland Hopkins, recently Sir William Dunn professor of biochemistry in the University of Cambridge; Dr. Alfred L. Kroeber, director of the Museum of Anthropology, University of California; Prof. The Svedberg, head of Physical Chemistry Institute, University of Uppsala; Prof. Arne Tiselius, professor of biochemistry, University of Uppsala. 